\title{
INTRODUCTION: MAPPING THE PLACE OF PHOTOGRAPHY IN FRENCH AND FRANCOPHONE CULTURES
}

\author{
KATHRIN YACAVONE
}

Photography as a visual medium of socio-cultural and artistic expression is the product, from a historical point of view, of primarily scientific advancements in the fields of optics and chemistry culminating in the mid-nineteenth century. The fertile crossing of the optical device of the camera obscura, a then already portable sealed box with a pinhole opening holding a lens which allowed for bundled light to enter, which then hit a back screen consisting of a light-sensitive plate thus registering an image (upside down, if it was no reversed by a mirror), and the chemical substances that served first to sensitize the plate and later fix the image obtained to protect it against vanishing, this new image production technology quickly advanced to become the first mass-medium in visual culture by the end of the nineteenth century. Beginning in 1839, the year of the public announcement of the invention, photography was put to a myriad of cultural uses, ranging from portraiture to anthropology, criminology and medicine; from landscape photography to documentary and land surveillance imagery; from amateur photography to war photography and emerging photojournalism. In the twentieth century, the application of photography to other social and cultural uses expanded even further, most notably into photo-based advertising and an increasingly selfreflexive artistic use since the European avant-garde movements of the 1920s and early 1930s. Even closer to our own times, in its digital guises, photography, or photo-realistic images, have spread exponentially via the Internet or other quotidian media channels. 
This classical, albeit cursory, account of the emergence and rapid spread of photographic images and the medium more generally goes hand in hand with perennial questions as to photography's disciplinary and discursive belonging, especially when compared to more established disciplines and discourses of visual art forms such as painting, for example. In the history and theory of photography these questions have themselves become part and parcel of photographic narratives, arguably enriching them even further. ${ }^{1}$ The present special issue of Nottingham French Studies foregrounds yet another question of belonging, namely the national, cultural and social place of photography in the hexagon and the wider francophone world. At first sight, photography may not readily be associated with 'typical' French culture, as is cinema, for example, one of its closest neighbours in the visual arts. In itself a mute medium (even if it is often closely related to spoken and written discourse, if not wholly dependent on it), ${ }^{2}$ photography may be seen to lack one of the most significant markers according to which national cultures and traditions are often identified and

\footnotetext{
${ }^{1}$ See the recent study by Hilde Van Gelder and Helen Westgeest, Photography Theory in
} Historical Perspective. Case Studies from Contemporary Art (Chichester: Wiley-Blackwell, 2011), who investigate photography as explicitly related to other visual media, such as painting, cinema, video and performance. By contrast, James Elkins has attempted to describe photography as completely detached from any discourse traditionally attached to it, see What Photography Is (New York and London: Routledge, 2011).

${ }^{2}$ For a wide-ranging discussion of photography's relation to language, see Clive Scott, The Spoken Image. Photography and Language (London: Reaktion, 1999). Already in his 1960s, the semiotic work on photography by Roland Barthes began to problematize these issues, see 'Rhétorique de l'image', in Euvres complètes, ed. by Éric Marty, 5 vols. (Paris: Seuil, 2002), vol. 2, pp. 573-88. 
institutionalized. Therefore, what is, or could be, the cogent connection between photography and French and francophone culture, and, by extension, the study of these areas abroad? What, if any, is the relevance of this particular visual medium to the cultural expression in France and the francophone world? And how may the place of photography in these cultural contexts be mapped, described or even justified?

The overarching purpose of this special issue is to begin to tackle these and other related questions in an attempt to understand the multifaceted nature and manifestations of the photographic medium in a specifically French-speaking context, both in terms of theory and practice. If one accepts that photography is not (yet?) readily associated with French and francophone culture, it nonetheless deserves more focused attention in this context and merits being examined within the confines of this historic-cultural framework. And this is for two interrelated reasons. Firstly, although the emergence of photography in the mid-nineteenth century was marked by fertile trans-national experimentation and intense rivalry between (at least) two nations (France and England), ${ }^{3}$ photography may be regarded as - at least in part a French invention, and this historical birthplace is of relevance to the extent that it may go some way towards accounting for the rich tradition in critical, historical and theoretical writing on photography in the French language, from Baudelaire to Barthes, to name but two of the most frequently discussed writers in any history or theory of photography. More generally, photography has been part of the ongoing project of understanding the process of modernity in Europe and France in particular. In this context, Walter Benjamin's ArcadesProject comes to mind, in which the German philosopher (who intermittently worked on this

\footnotetext{
${ }^{3}$ See the recent account of the early period of photographic history by Helen Rappaport and Roger Watson, Capturing the Light. The Birth of Photography: a True Story of Genius and Rivalry (London: Macmillan, 2013).
} 
unfinished magnum opus in the Parisian Bibliothèque nationale from the late 1920s to 1940) attempted to trace and establish an Ur-history of modernity in the light of nineteenth-century Paris and (predominantly) French culture. Photography was an integral part of this history as addressed by Benjamin. Yet, in our context, the emphasis of photography' relation to French culture and identity is perhaps less on the question as to how the former shapes the latter (Benjamin's project was in part on the impact of new image-production technologies on society and culture), but instead on how the photographic medium and the discourses surrounding it may help to conceptually as well as historically understand, express and reflect upon the evolution of French and francophone culture and identity. The fact that photography has served as a medium of exploration of identity and belonging on the part of French and francophone photographers, artists and writers in the form of photographic bodies of work, autobiographical projects that combine photographic image and text (photobiography), or socalled photographic writing (as a palpable impact of photography on literary production emerging in the early twentieth century), speaks to the significance of this reciprocal relationship.

From w wider perspective, as part of the oft-cited 'pictorial turn' of the 1990s, socalled French theory has (re-)entered centre stage of theoretical and critical debate around the visual. ${ }^{4}$ In this context, photography is often absorbed into discourses on 'visual culture' with the danger perhaps of losing sight of photography's specificities (its histories, theories, mythologies, uses and misuses, etc.). However, even if theories of visual culture or theories of

\footnotetext{
${ }^{4}$ See Martin Jay's important study Downcast Eyes: The Denigration of Vision in TwentiethCentury French Thought (Berkeley: University of California Press, 1993) and the more recent essay collection by Nigel Saint and Andy Stafford (eds.), Modern French Visual Theory. A Critical Reader (Manchester and New York: Manchester University Press, 2013).
} 
the image dovetail with changes that photography and other visual media have been undergoing for at least the last twenty-five years or so (notably owing to digitization), resulting in a notable blurring of strictly medium-defined boundaries, these developments by no means invalidate or reject the value and necessity of historical and theoretical discourses of photography and its specific properties, - without, however, subscribing to an overdetermined understanding of medium-specificity, characteristic of the art historical approach associated with Clement Greenberg and subsequently Rosalind Krauss. In short, just as theories of visual culture do not challenge, but rather co-exist and productively intersect with, art history, so too, theories of photography sit alongside and dialogue with these wider trends in the broader field of French theory; but, leaving photography to only the latter would risk neglecting a rich and valuable aspect of the medium.

This, then, brings me to the second related reason for why it may be time for photography to enter more visibly in the canon of subjects studied as part of French and francophone culture, which is that its study is overdue; especially considering the increasingly inter-disciplinary, area and culture studies orientation of the discipline in recent years. ${ }^{5}$ Indeed, although there is a brief entry on photography in the 1998 Encyclopedia of Contemporary French Culture, ${ }^{6}$ the recent landmark publication on French Studies in and for the Twenty-first Century, which claims to 'offer a picture of French Studies today, an analysis - from the inside - of what the discipline has become and where it might and, indeed, must go

\footnotetext{
${ }^{5}$ See the brief historical overview by Diana Holmes, 'A Short History of French Studies in the UK', in French Studies in and for the Twenty-first Century, ed. by Philippe Lane and Michael Worton (Liverpool: Liverpool University Press, 2011), pp.12-24.

${ }^{6}$ See Michael Worton, 'Photography', in Encyclopedia of Contemporary French Culture, ed. by Alex Hughes and Keith Reader (London and New York: Routledge, 1998), pp. 421-3.
} 
in the future', ${ }^{7}$ makes no reference to photography. Photography, it seems, falls between the cracks of discussion of cinema, popular culture and word-and-image studies on the one hand and area and culture studies on the other (all addressed in the volume). Given the distinct link of French culture to photographic history and its wider discourses and expressions, already hinted at, this lack of engagement with the medium in a discipline-defining manifesto is curious. At the same time, it speaks to the symptomatic in-visibility of photography in the established curriculum of French and francophone studies, which is rooted, in part at least, as I already suggested, in the fact that photography is silent. And yet, scholarship in the discipline has paid increasing attention to photography, albeit predominantly from a more traditional, literary studies perspective, often under the more general headings of 'photo-text' or 'photobiography'. ${ }^{8}$ Thus we find a, perhaps typical, paradoxical situation with regards to photography: while it has been addressed by scholars in French studies for a number of years, if not decades, producing a small but rich body of work, French studies as an institutionalized discipline (in the UK, at least) has so-far neglected to head-on address photography as a form of socio-cultural expression. As is also demonstrated by the contributors to this volume, photography is at the centre of much current research, often inter-disciplinary, but still within

\footnotetext{
${ }^{7}$ Philippe Lane and Michael Worton (eds.), French Studies in and for the Twenty-first Century (Liverpool: Liverpool University Press, 2011), p. 3.

${ }^{8}$ André Breton's inclusion of photographic images in his photo-roman Nadja in 1928 marks the beginning of the more direct interaction between photography and literature. However, even before the actual use of photographic images in literary works, a number of nineteenthand early-twentieth-century writers, such as Baudelaire, Zola and Proust, have been under the spell of photography and have been studied in this light.
} 
the realm of French studies, reflecting the rich tradition of photography in historical, cultural and artistic French and francophone contexts.

This collection of articles partially draws on papers first presented at a study day on the topic of photography in France at the University of Nottingham in June 2011. ${ }^{9}$ Initially focused on the period from the 1990s to the present day, as two decades following the major shift from analogue to digital image making and viewing, it quickly became clear that in order more fully to understand the developments and trends in the contemporary era, it was necessary to move further back in time, to the $1970 \mathrm{~s}$ - a decade of important institutional developments in photographic history. Thus, the essays here presented stretch a broader timeframe, without losing sight of the main focus on contemporary debates and developments. The organization does not follow any chronology or hierarchy; instead articles have been arranged in a way for four interrelated thematic concerns to emerge: wider institutional, political and art-historical debates surrounding photography in France; contemporary practice of French photographers working on city photography; photography's interrelation with processes of creating, reflecting and questioning French and francophone identities; photography's relation to different forms and genres of literary writing.

Accordingly, the first article looks at the current landscape of photographic institutions in France and traces the complex and by no means straightforward history of photography's cultural institutionalization from the 1970s onwards. My aim with this contribution is to show

\footnotetext{
${ }^{9}$ Participants of this conference included Fabien Arribert-Narce, Shirley Jordan, Akane Kawakami, Joseph McGonagle, Olga Smith and Andy Stafford. I wish to thank my colleagues at Nottingham, the Society for French Studies and the School of Cultures, Languages and Area Studies at the University of Nottingham for supporting this event as well as this publication.
} 
that the place of photography in contemporary French culture is not a default position, but one that has been actively promoted and even fought for by individuals and institutions alike. The more centralized and co-ordinated cultural politics of photography emerging in the early 1980s, by contrast, must be understood as a reaction to changes in photographic practice and discourses on the ground. And although photography's present visibility is primarily owing to its affinities to the art world, art exhibitions and galleries, key institutions such as the Maison européenne de la photography and the Bibliothèque nationale de France show that it is located and promoted in a much broader remit of national institutions. The interview with the founder and director of the former organization, Jean-Luc Monterosso, provides a valuable first-hand account of the cultural institutionalization of photography, especially in a Parisian context. However, as Monterosso indicates, photography also lends itself to an inter-national cultural exchange that defies boundaries of institutions in a similar way as digitization has begun to challenge traditional modes of production and dissemination of photography. Magali Nachtergael's contribution takes up the baton from this wider overview of the relations between a new understanding of photography as art and photographic institutions by focusing more closely at the specific theoretical debates emerging in the 1980s and 1990s in dialogue with new photographic practices in France. Centred on the notion of 'photographie plasticienne', coined by Dominique Baqué in the late 1990s, Nachtergael analyses the theoretical and historical tensions, but also overlaps, of a complex debate in which modernist positions, with an emphasis on the aesthetic quality of the photographic image as well as the autonomy of the medium, largely oppose the umbrella term of 'photographie plasticienne', with its emphasis on the medial hybridity of contemporary practice in photography after conceptual art.

Following Nachtergael's contextual and historical reference to Jean-François Chevrier's concept of 'photo-tableau' as an acknowledgement of photography's arrival in the 
wider sphere of the fine arts, Olga Smith investigates this category in more detail in relation to the photographic work of Valérie Jouve. With careful attention to composition and visual details of Jouve's urban photography, Smith explores the multi-layered significance of 'containment', as applied to the relation between the human body and its social as well as architectural environment, the topographical relation between the centre of Paris and the banlieue, and finally, in drawing on Chevrier's concept of tableau, the framing of the photographic space as representation. This latter, she suggests, speaks to the reflexive aspect of Jouve's urban portraits in which the sitters' and the viewers' contemplative attitudes correspond to one another, thus creating a distinct documentary aesthetic. The photograph's potential as both document and art is a theme also central to Shirley Jordan's discussion of Stéphane Couturier. Still in the context of photography of the urban environment, Jordan demonstrates how Couturier's photographs, in visual dialogue with nineteenth- and twentiethcentury predecessors in photography and painting, creates palimpsestual images of rapid urban transformation in France and elsewhere. She argues that these photographs through subject matter, composition, colour and size ceaselessly oscillate between archive and collapse of memory, creating indeterminacy in the viewer's reaction to, and engagement with these images, rooted in him or her equally being caught between past and future as a reflection of the transience of urban change.

Whereas Smith and Jordan analyse photography concerned with the city in an explicit and, at times, self-reflexive art photography context, the following two contributions consider wider territorial changes in relation to French and francophone identity, thus also expanding the discussion to include questions about photography's role in (co-)shaping and expressing the relation between the hexagon and Algeria. Edward Welch's article takes as it starting point Michel Houellebecq's 2010 novel La Carte et le territoire in order to explore the impact of visual imagery and photography especially on the understanding of national territory and 
identity in contemporary France with respect to Raymond Depardon's photographic œuvre of the first decade of the twenty-first century. Unlike the state-funded, centralized land surveillance projects such as those commissioned by the DATAR in the 1980s, Depardon's photographs of rural France, Welch argues, offer a more engaged (self-) reflection of life in the hexagon while simultaneously reaffirming the traditional use of photography as a privileged means to explore identity and spatial territory in the wider modernization process of post-war France. A potentially uneasy relation between official, state-led representation and more personal, artistic endeavours to capture one's own as well as one's nation identity is addressed in more head-on post-colonial terms in Amanda Crawley Jackson's contribution. Against the backdrop of the Algerian 'guerre sans images' of the 1990s, she analysis Bruno Boudjelal's photographic work, which he amassed together with written commentary during a number of travels to Algeria to explore both his personal family history and the recent collective history of the country. Crawley Jackson demonstrates how the photographic medium helps Boudjelal to explore and express these histories in a non-linear fashion and how his images self-reflexively question notions of documentary authenticity as much as his journeys to Algeria deny discovery of a stable cultural and self-identity.

The final pair of articles by Fabien Arribert-Narce and Akane Kawakami turns to a more self-centred exploration of identity and selfhood in the form of autobiographical narratives - or the predominantly French phenomenon of autofiction and photobiographie that include or refer to photographic images (real or imaginary). In this regard, Arribert-Narce proposes a two-pronged taxonomy of photobiographical texts in French from the 1970s to the present day. He distinguishes between two broad tendencies, a notational and ficitionalizing type of photobiography, and defines the former as based on the largely documentary function of the photographic image and its apparent referentiality whereas the latter presents these same properties as an obstacle to imaginary self-exploration and reflection. Evaluating works 
by a number of key writers/photographers along these lines (from Roland Barthes, J.M.G. Le Clézio and Denis Roche to Hervé Guibert, Marguerite Duras and Sophie Calle), ArribertNarce reflects on a wide range of photobiographical writing. Kawakami, on the other hand, zooms in on the specific body of writings by Annie Ernaux prominently preoccupied with photography in its multi-faceted relation to literature. Focused on 1989 as a particularly prolific year in Ernaux's diary writing, Kawakami demonstrates how the author's autoethnographical œuvre produces a multi-perspectival reflection on her self as writer and her self-writing. Through an analysis of Ernaux's complex deployment of photography as metaphors and stylistic and narratological analogies in her diaries, Kawakami's contribution concludes this special issue on a meta-level, as it were, suggesting that Ernaux's works create in themselves a multi-layered photograph of the author.

On the whole, and despite its broad and inclusive remit, this special issue does not propose to be a comprehensive survey of contemporary manifestations and application of photography in French and francophone cultures; instead it marks a beginning, I would hope, of a more visible engagement with photography as a distinct form of cultural expression in the French-speaking world. From this perspective, it becomes clear that in addition to the rich tradition of photographic metaphors, tropes and analogies in French-speaking literature, photography is a visual medium with great potential for investigations and explorations into what 'Frenchness' in the twenty-first century is or may be. Indeed, as the contributions here assembled aim to demonstrate, photography does occupy a significant, albeit self-reflexively unstable, place in contemporary French and francophone cultures; a place whose further acknowledgement and celebration, both within French and francophone society and culture and within the discipline, this collection aims to stimulate. 